\title{
Effect of andiroba oil on periodontitis in Wistar rats ${ }^{1}$
}

\author{
Glaucia Babeto Carmona', Renan Kleber Costa Teixeira" ${ }^{\mathrm{II}}$, Marcus Vinicius Henriques Brito ${ }^{\mathrm{III}}$, Flavia Sirotheau Correa \\ Pontes $^{\text {IV }}$, Eloisa Helena Aguiar Andrade ${ }^{\text {V }}$, Felipe Paiva Fonseca ${ }^{\text {VI }}$, Ricardo Miranda Brito Costa ${ }^{\text {VII }}$, Francideise Martins \\ Carvalho $^{\mathrm{VIII}}$
}

IFelow Master degree, Postgraduate Program in Odontology, UFPA, Belem-PA, Brazil. Conception and design of the study, surgical procedures, manuscript writing.

${ }^{\mathrm{II}}$ Graduate student, State University of Para (UEPA), Brazil. Interpretation of data, statistical analysis, manuscript writing.

IIIPhD, Associate Professor, Medical School, UEPA, Para, Brazil. Conception and design of the study, interpretation of data, final revision.

${ }^{\text {Iv }} \mathrm{PhD}$, Associate Professor, Odontology School, UFPA, Belem-PA, Brazil. Critical revision.

${ }^{\vee} \mathrm{PhD}$, Associate Professor, Odontology School, UFPA, Belem-PA, Brazil. Critical revision.

${ }^{v 1}$ Felow Master degree, Postgraduate Program in Odontology, UFPA, Belem-PA, Brazil. Histometric analysis, critical revision.

${ }^{\mathrm{VII}}$ Graduate student, UEPA, Para, Brazil. Surgical procedures, manuscript writing.

${ }^{\mathrm{VIII}}$ Graduate student, UEPA, Para, Brazil. Score of inflammatory cells.

\section{ABSTRACT \\ PURPOSE: To evaluate the effects of andiroba oil on the periodontitis in rats.}

METHODS: The periodontitis was induced by the placement of cotton ligatures around the cervix of the second upper molars on fifteen rats, and waiting fifty days. The animals were randomly distributed into three groups: saline group, andiroba oil group and meloxican group, differentiated by substance used in the treatment of periodontitis. The groups received the respective substance by gavage for seven days, after the periodontitis induced. It was analyzed the score of inflammatory cells and the measurement from the cementoenamel junction to the bone crest.

RESULTS: The andiroba oil group $(\mathrm{p}=0.008)$ and meloxican group $(\mathrm{p}=0.0347)$ show a less score of inflammatory cells than saline group, however there weren't difference between them $(\mathrm{p}=0.2754)$. Regarding the analysis of measurement from the cemento-enamel junction to the bone crest, there was no difference between groups studied $(p=0.3451)$.

CONCLUSION: Andiroba oil decreased the quantity of inflammatory cells, however, it didn't have an effect on the measurement of alveolar bone loss, like the treatment with Meloxican ${ }^{\circledR}$.

Key words: Periodontitis. Bone Resorption. Anti-Inflammatory Agents. Rats. 


\section{Introduction}

The oral cavity is a natural reservoir of thousands of micro-organisms with a high potential for infection ${ }^{1}$. When associated with a poor oral hygiene and / or indiscriminate use of antibiotics can easily cause a differentiated of the microbiota on this area of the body ${ }^{1,2}$.

This colonization can progress to the formation of periondontal disease that is characterized as an infectious disease that results in the destruction and degradation of periodontal tissues by the local action of periodontopathogenic microorganisms ${ }^{3}$. These microorganisms release substances that lead to progressive destruction of structures supporting the teeth: the periodontal ligament, the alveolar bone and gingival tissues ${ }^{4,5}$.

The periodontitis, a chronic inflammatory oral disease, affects a major part of world's population characterized by localized or generalized bone resorption, reaching about $10-15 \%$ of the adult population ${ }^{6}$. And these rates are very high in patients with diabetes ${ }^{7}$, hypertension ${ }^{8}$ or smoking 9 .

The treatment of periodontitis is the reduction or elimination the present periodontal bacteria ${ }^{10}$, however, the mechanical therapy as the only therapeutic modality may fail to eliminate harmful bacteria present in the soft tissue, and there is also an aggravating factor in inaccessible areas to periodontal instruments, such as surfaces of the root bifurcation and depressions ${ }^{11}$.

Because of it, researches were conducted in an attempt to improve the clinical management of this condition and is much used the administer of local and systemic antibiotics to control bacteria present on the periondotitis ${ }^{12,13}$. However the antibiotics must be properly used to avoid the selection of new resistant bacteria. But now already can be see that due to the indiscriminate use of antimicrobials by the population for the treatment of many diseases, eventually select multiple etiological agents of oral flora, making them resistant to the use of several conventional antimicrobials $^{14}$.

The use of medicinal plants is a growing practice in developed countries and a widely used therapy in developing countries. This practice is currently being promoted by the World Health Organization ${ }^{15}$. A plant of featured on Amazon is the Andiroba, whose oil is attributed to several properties by local people, some of these have been scientifically proven, the most prominent being the anti-inflammatory and antimicrobial $\operatorname{activities}^{16,17}$.

The use of medicinal plants have great importance to science, since these can be extracted from the active principles of great therapeutic value, but the indiscriminate use of these can bring harm to health, since there are few studies that verify the potential harms these in the body. The objective of this study is to evaluate the effects of andiroba oil orally administered on experimental periodontitis induced in rats.

\section{Methods}

Approved by the Ethics Committee in the Use of Animals of the State University of Para (UEPA), protocol 40/11. This study used the andiroba oil species Carapa guianensis, supplied by EMBRAPA, previously submitted to a physicochemical analyze to define its composition.

Fifteen male Wistar rats (Rattus norvegicus) were used, weighing between 210 - 250 grams, provided from the Animal Colony of the Experimental Surgery Laboratory of UEPA. They were kept in a controlled environment, with food and water ad libitum.

The periodontitis was induced in all animals. For that, the rats were anesthetized with ketamine hydrochloride $(70 \mathrm{mg} / \mathrm{Kg})$ and xylazine hydrochloride $(10 \mathrm{mg} / \mathrm{Kg})$, intraperitoneally.

Then, The animals had their oral tissues disinfected with chlorhexidine $0.12 \%$ and cotton ligatures (brand: Corrente ${ }^{\circledR}, \mathrm{n}^{\mathrm{o}}$ 24) were placed around the cervix of the second upper molars (Figure 1). Fifty days was the period considered enough for the periodontitis induction.

After that they were randomized distributed into three study groups, with five animals each:

- $\quad$ Saline Group (GS): treated with $0.63 \mathrm{ml} / \mathrm{Kg}$ of $\mathrm{NaCl} 0.9 \%$ by gavage $^{17}$;

Andiroba oil Group (GA): treated with $0.63 \mathrm{ml} / \mathrm{Kg}$ of andiroba oil by gavage ${ }^{17}$;

Meloxican Group (GM): treated with $7.5 \mathrm{ml} / \mathrm{Kg}$ of meloxican by gavage ${ }^{18}$.

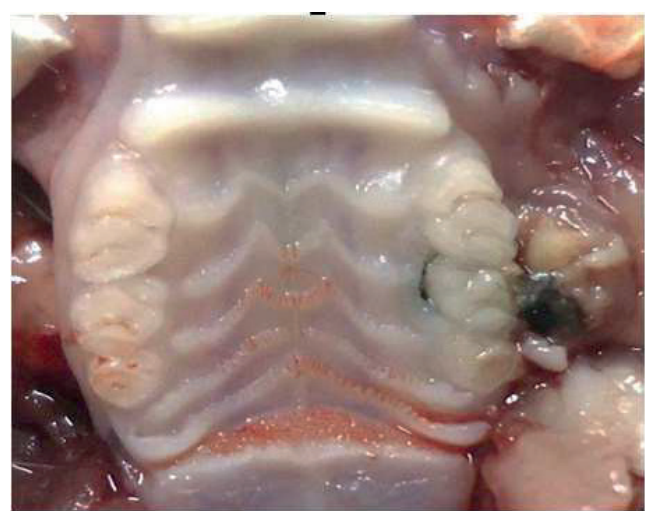

FIGURE 1 - Oral cavity of the animal with the ligature. 
After the fifty days of periodontitis induction, the animals were treated with saline $(0.63 \mathrm{~mL} / \mathrm{Kg})$, andiroba oil $(0.63 \mathrm{~mL} / \mathrm{Kg})$ and meloxican $(7.5 \mathrm{~mL} / \mathrm{Kg})$, according the respective group, by gavage, for seven days, once a day.

The maxilla was removed after animals' euthanasia, the gingival tissue was preserved. The fragments were fixed in $10 \%$ formalin for 48 hours and decalcified in $10 \%$ nitric acid. So, after included in paraffin, they were processed to obtain $4 \mu \mathrm{m}$ thick serial sections, which were made in buccolingual direction to compose histological blades. The specimens were stained with hematoxylin and eosin coloration. Score of inflammatory cells and measurement from the cemento-enamel junction to the bone crest were performed.

The score of inflammatory cells were observed by an optical microscopy Nikon Eclipse E-200 model. It was used increase of $\mathrm{x} 4, \mathrm{x} 10$ and $\mathrm{x} 40$. After that, the last increase was photographed with a standard camera Panasonic FS42 10.1 megapixel. The goal was to focus the area of connective tissue between the bottom of the epithelium to the alveolar bone crest. A previous trained, single blinded examiner was able to count the inflammatory cells (lymphocytes, plasmocytes, eosinophils) using the program Image ${ }^{\circledR} 1.45 \mathrm{~s}$.

After scanning all the blades (Aperio ScanScope $\mathrm{CS}^{\odot}$ Aperio Technologies, Vista, CA, USA), a trained observer, blinded to the group, used the software ImageScope ${ }^{\circledR}$ to obtain an oblique measurement from the cemento-enamel junction to the bone crest (Figure 2).

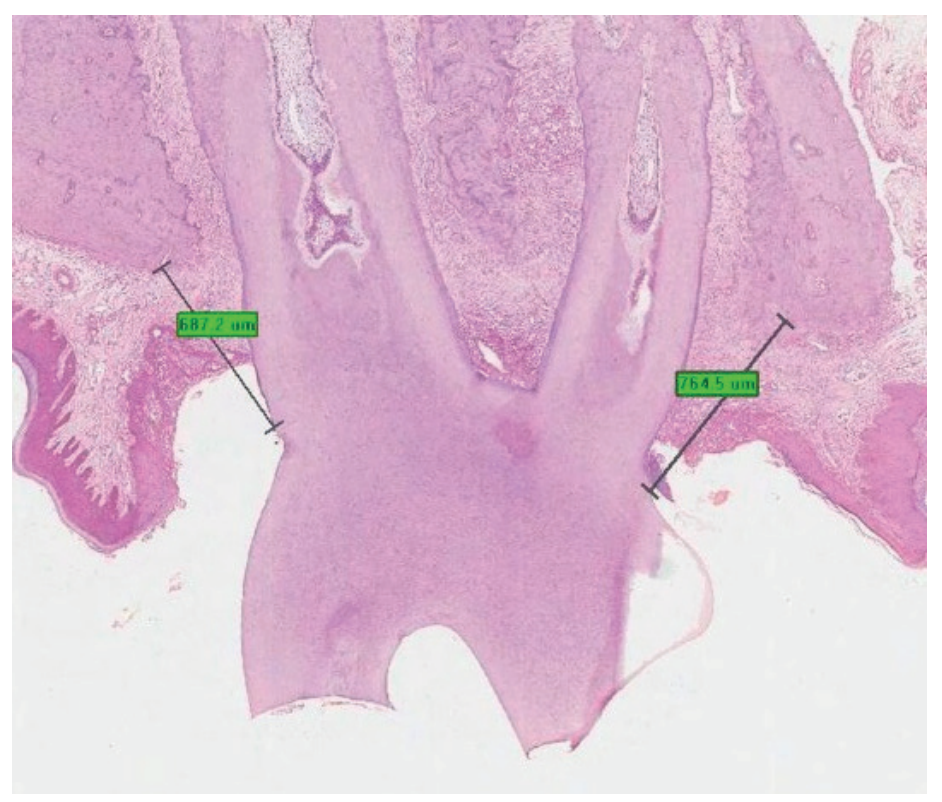

FIGURE 2 - Figure shows the measurement from the cemento-enamel junction to the bone crest.
Statistical analysis was performed with the program Bioestat $5.3^{\circledR}$. All the data were underwent to normality test (Shapiro-Wilk). Replicability was tested by intraclass correlation. The medians (Md) and Interquartile deviations were presented in the graphics. Kruskall Wallis test was applied, considering a p-value less than 0.05 as significant.

\section{Results}

During the 50 days, no animals died, however, three animals were replaced because the ligature were missing. All animals showed an inflammatory reaction around teeth with the ligature.

The score of inflammatory cells were described in Figure 3 . In the GS was identified $32.13 \pm 15.41$ inflammaroty cells, in the GA was identified $14.72 \pm 10.26$ cells and on the GM was identified $20.42 \pm 16.19$ cells, that have a statistically significant difference between the andiroba oil group $(\mathrm{p}=0.008)$ and meloxican group $(p=0.0347)$ than Saline group, although there were no diference between the andiroba oil group and meloxican group $(\mathrm{p}=0.2754)$.

\section{Count of inflammatory cells}

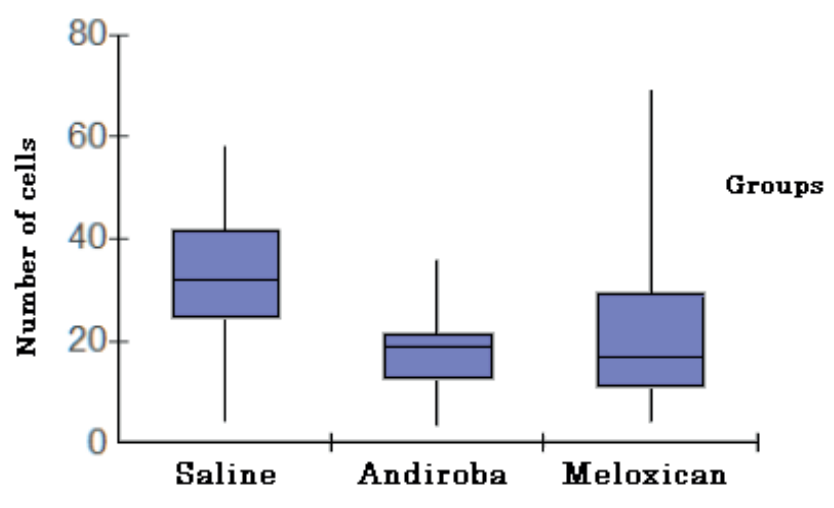

FIGURE 3 - Score of inflammatory cells according to each group.

Regarding the histometric analysis, there was no difference between groups studied in relation to the measurement from the cemento-enamel junction to the bone crest $(\mathrm{p}=0.3451)$. The Table 1 shows the averages of the measurement according to each group. 
TABLE 1 - Averages of the measurement from the cemento-enamel junction to the bone crest according to each group.

\begin{tabular}{cc} 
Group & Distance $(\mathrm{mm})$ \\
\hline GS & $0.619 \pm 0.304$ \\
GA & $0.754 \pm 0.239$ \\
GM & $0.645 \pm 0.239$ \\
\hline
\end{tabular}

Source: Research protocol $\mathrm{p}=0.3451$ (Kruskall Wallis)

\section{Discussion}

Periodontal disease is a disease neglected by much of the population due to present little or no immediate clinical impact, being considered by the lay population only as an aesthetic problem. However, this disease can present systemic repercussions, especially cardiac and infectious, the example of infective endocarditis ${ }^{2,3,19}$.

Only the mechanical treatment for the periodontitis is, sometimes, not enough to completely eliminate the bacteria present. The use of antibiotics to treat this disease was not effective due to the resistance of microorganisms and variety of oral flora ${ }^{10,11}$. Thus, the search for new fonts of treatment is important to this pathology. In this context there is the andiroba, an Amazon region plant, which has antibiotics and anti-inflammatories effects proven $^{16,17}$.

The periodontitis experimental model is widely used in literature, featuring $100 \%$ chance of causing tissue disease, after the minimum period of 30 days ${ }^{12}$, however It was used the period of 50 days to ensure greater bone loss, showing more efficiently effects of oil andiroba ${ }^{20}$. This model generates an accumulation of plaque around the cotton ligature. This simulates the human tooth plaque with physipathological repercussions ${ }^{3,4,5}$.

Regarding the inflammatory score, the andiroba oil decreased the number of inflammatory cells identified in histology with a similar effect of meloxicam, with anti-inflammatory effects demonstrated in periodontitis ${ }^{18}$. The chronic inflammation is the main mechanism that promotes the destruction and dental fragility, facilitating the occurrence of bacteremia. In addition to continuing production of interleukins and cytokines induce exacerbation of thromboembolic phenomena and atherosclerotic $\mathrm{c}^{3,4,19}$.

However, even reducing the inflammatory response andiroba oil had no effect on the extent of loss dental alveolar bone. This parameter is the primary evaluator of recovery and healing of periodontal disease ${ }^{2,3}$. The recovery of this barrier has a fundamental importance to avoid bacteremia during feeding or dental procedures.

In several studies with similar methodology $y^{6,12,13,18}$, but with different substances testing, was found decreased inflammatory response but was not shown difference on the measurement from the cemento-enamel junction, this fact probably occurs because the short time of analysis after application of substances, which is usually after seven days. Thus, further researches are necessary to observe how much time is appropriate to manage the substances for the recovery of bone loss. So that will encourage future studies to adopt this new period.

The andiroba oil showed satisfactory effects in an induced periodontitis in rats in a systemic administration. Because of the anti-inflammatory and antibacterial agents, the andiroba topically administered or inside dental dentifrices would probably lead to better results. The concentration of the best active principles of the plant associate with mechanic therapy would improve the clinical outcames ${ }^{13}$. New studies are required to verify the effects of the oil in these two distinct ways of administration.

\section{Conclusion}

Andiroba oil decreased the quantity of inflammatory cells. However, it didn't have effectiveness on the measure of alveolar bone loss, like the treatment with meloxican.

\section{References}

1. Gonçalves MO, Coutinho-Filho WP, Pimenta FP, Pereira GA, Pereira JAA, Mattos-Guaraldi AL, Hirata R Jr. Periodontal disease as reservoir for multi-resistant and hydrolytic enterobacterial species. Lett Appl Microbiol. 2007;44:488-94.

2. Gaetti-Jardim E Jr, Nakano V, Wahasugui TC, Cabral FC, Gamba $\mathrm{R}$, Avila-Campos MJ. Occurrence of yeasts, enterococci and other enteric bacteria in subgingival biofilm of HIV-positive patients with chronic gingivitis and necrotizing periodontitis. Braz J Microbiol. 2008;39:257-61.

3. Van Dyke TE. The etiology and pathogenesis of periodontitis revisited. J Appl Oral Sci. 2009;17(1).

4. Kinane DF. Causation and pathogenesis of periodontal disease. Periodontol 2000. 2001;25:8-20.

5. Graves DT, Li J, Cochran DL. Inflammation and uncoupling as mechanisms of periodontal bone loss. J. Dent Res. 2011;90(2):14353.

6. Botelho MA, Rao VS, Montenegro D, Bandeira MA, Fonseca SG, Nogueira NA, Ribeiro RA, Brito GA. Effects of a herbal gel containing carvacrol and chalcones on alveolar bone resorption in rats on experimental periodontitis. Phytother Res. 2008;22(4):4429.

7. Anner R, Grossmann Y, Anner Y, Levin L. Smoking, diabetes mellitus, periodontitis, and supportive periodontal treatment as factors associated with dental implant survival: a long-term retrospective evaluation of patients followed for up to 10 years. 
Implant Dent. 2010;19(1):57-64.

8. Vidal F, Figueiredo CMS, Cordovil I, Fischer RG. Higher prevalence of periodontitis in patients with refractory arterial hypertension: a case-control study. Oral Dis. 2011;17(6):560-3.

9. Heitz-Mayfield LJ, Huynh-Ba G. History of treated periodontitis and smoking as risks for implant therapy. Int J Oral Maxillofac Implants. 2009;24:36-68.

10. Kaldahl WB, Kalkwarf KL, Patil KD. A review of longitudinal studies that compared periodontal therapies. J Periodontol. 1993;64(4):243-53.

11. Adriaens PA, Edwards CA, De Boever JA, Loesche WJ. Ultrastructural observations on bacterial invasion in cementum and radicular dentin of periodontally diseased human teeth. J Periodontol. 1988;59(8):493-503.

12. Fernandes LA, Martins TM, Almeida JM, Nagata MJH, Theodoro LH, Garcia VG, Bosco AF. Experimental periodontal disease treatment by subgingival irrigation with tetracycline hydrochloride in rats. J Appl Oral Sci. 2010;18(6):635-40.

13. Botelho MA, Martins JG, Ruela RS, Queiroz DB, Ruela WS. Nanotechnology in ligature-induced periodontitis: protective effect of a doxycycline gel with nanoparticules. J Appl Oral Sci. 2010;18(4):335-42.

14. Gaetti-Jardim EC, Marqueti AC, Faverani LP, Gaetti-Jardim Junior E. Antimicrobial resistance of aerobes and facultative anaerobes isolated from the oral cavity. J Appl Oral Sci. 2010;18(6):551-9.

15. Akerele O. Summary of WHO guidelines for assessment of herbal medicines. HerbalGram. 1993;28:13-9.

16. Brito MVH, Figueiredo RC, Tavares MLC, Silveira TS, Cantanhêde G. Efeito dos óleos de andiroba e copaíba na miosite induzida em ratos. Rev Para Med. 2006;20(2):17-24.

17. Rodrigues BD, Fonseca AXC, Brito MVH, Brito NMB, Brito RB. Efeito do óleo de andiroba na isquemia e reperfusão renal em ratos. Rev Para Med. 2008;22(2):9-16.

18. Nassar CU, Nassar PO, Inagaki NS, Girelli Júnior C. The effect of anti- inflammatory drug in the development of induced periodontal disease: radiographic evaluation in rats. Rev Odontol UNESP. 2003;32(2):125-30.

19. Zanella SM, Souza LV, Suzigan BH, Saba-Chujfi E, Barbisan $J \mathrm{~N}$. Associação entre saúde bucal e doença arterial coronária aterosclerótica em pacientes submetidos a cineangiocoronariografia: estudo transversal controlado. Rev Bras Cardiol Invasiva. 2012;20(2):178-83.

20. Semenoff TADV, Semenoff-Segundo A, Bosco AF, Nagata MJH, Garcia VG, Biasoli ER. Histometric analysis of ligature-induced periodontitis in rats: a comparison of histological section planes. J Appl Oral Sci. 2008;16(4):251-6

\section{Correspondence:}

Glaucia Babeto Carmona

Rua Antonio Barreto, 1070

66055-050 Belém-PA Brasil

Tel.: (55 91)8897-6446

glaubrc@hotmail.com

Received: February 26, 2013

Review: April 24, 2013

Accepted: May 21, 2013

Conflict of interest: none

Financial source: none

${ }^{1}$ Research performed at Experimental Surgery Laboratory, School of Medicine, State University of Para (UEPA), Belem-PA, Brazil. Part of Master degree thesis, Postgraduate Program in Odontology, UFPA. Tutor: Marcus Vinicius Henriques Brito. 